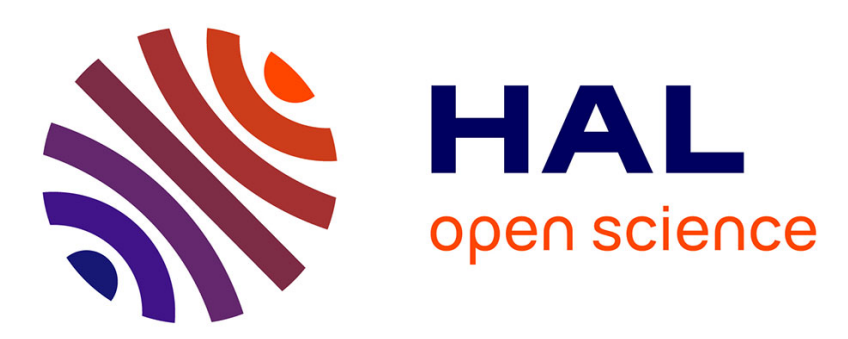

\title{
Ceramic Standardization and Intensity of Production: Quantifying Degrees of Specialization
}

\author{
Valentine Roux
}

\section{To cite this version:}

Valentine Roux. Ceramic Standardization and Intensity of Production: Quantifying Degrees of Specialization . American Antiquity, 2003, 68 (4), pp.768-782. 10.2307/3557072 . halshs-00004793

\section{HAL Id: halshs-00004793 \\ https://shs.hal.science/halshs-00004793}

Submitted on 9 Oct 2017

HAL is a multi-disciplinary open access archive for the deposit and dissemination of scientific research documents, whether they are published or not. The documents may come from teaching and research institutions in France or abroad, or from public or private research centers.
L'archive ouverte pluridisciplinaire HAL, est destinée au dépôt et à la diffusion de documents scientifiques de niveau recherche, publiés ou non, émanant des établissements d'enseignement et de recherche français ou étrangers, des laboratoires publics ou privés. 
Ceramic Standardization and Intensity of Production: Quantifying Degrees of Specialization Author(s): Valentine Roux

Source: American Antiquity, Vol. 68, No. 4 (Oct., 2003), pp. 768-782

Published by: Cambridge University Press

Stable URL: http://www.jstor.org/stable/3557072

Accessed: 09-10-2017 08:58 UTC

\section{REFERENCES}

Linked references are available on JSTOR for this article: http://www.jstor.org/stable/3557072?seq=1\&cid=pdf-reference\#references_tab_contents You may need to log in to JSTOR to access the linked references.

JSTOR is a not-for-profit service that helps scholars, researchers, and students discover, use, and build upon a wide range of content in a trusted digital archive. We use information technology and tools to increase productivity and facilitate new forms of scholarship. For more information about JSTOR, please contact support@jstor.org.

Your use of the JSTOR archive indicates your acceptance of the Terms \& Conditions of Use, available at http://about.jstor.org/terms

Cambridge University Press is collaborating with JSTOR to digitize, preserve and extend access to American Antiquity 


\title{
CERAMIC STANDARDIZATION AND INTENSITY OF PRODUCTION: QUANTIFYING DEGREES OF SPECIALIZATION
}

\author{
Valentine Roux
}

\begin{abstract}
The aim of this study is to examine the relationship between metric variability of ceramic vessels of a single type and intensity of production. This relationship is examined on the basis of vessels made by Indian and Spanish potters whose rates of production vary from low to high. Results are compared with Filipino data to embrace different cultures and therefore possibly different emic conceptions of standardization. We conclude that rate of production affects the degree of standardization. However, only in a high-rate production situation do we have motor habits that transcend emic conceptions of standardization. Indeed, factors like size classes, emic conception of size classes, and skill may induce a certain variability despite similar rates of production. Indexing degrees of standardization needs, in other respects, to take into account the cumulative effect of production events that play on the CV (Coefficient of Variation) values. Applied to Mesopotamian data, our results suggest that third millennium ceramic production can be compared to low-rate production observed ethnographically.
\end{abstract}

El propósito de este estudio es analizar la relación entre la variabilidad métrica de las vasijas de un solo tipo cerámico y la intensidad de la producción. Esta relación se estudia a partir de una serie de piezas manufacturadas por alfareros de la India y de España cuya producción puede variar en cantide de baja a alta. Los resultados se comparan con datos de los filipinos para abarcar diferentes culturas y, por lo tanto, posibles diferencias en conceptos émicos de estandarización. Concluimos que la tasa de producción incide en el nivel de estandarización. Sin embargo, solamente en caso de una tasa alta de producción hay habitos de manufactura que transcienden los conceptos émicos de estandarización. En efecto, factores como las clases de dimensiones, los conceptos émicos del tamaño y la destreza del artesano producen cierta variabilidad a pesar de que haya tasas similares de producción. Para medir los grados de estandarización se requiere, entre otros aspectos, tomar en cuenta el efecto acumulativo de los eventos de producción sobre los valores del CV (coeficiente de variación). Al aplicar estos resultados a los datos de Mesopotamia, se cuenta con bases para plantear que la producción de ceramica en el tercer milenio puede ser comparada con una producción de nivel bajo tal como se lo ha observado en contextos etnográficos.

I $\mathrm{n}$ archaeology, the degree of ceramic standardization is taken to reflect intensity of production and degree of specialization. The standardization hypothesis (e.g., Costin 1991, 2000; Costin and Hagstrum 1995) proposes that more uniformity is due to a higher rate of production. The latter is correlated with economic specialization, which encompasses many ways to organize craft production (domestic $v s$. specialized production, part-time $v s$. full-time potters, attached $v s$. independent potters, individual vs. workshop, etc.) (e.g., Arnold and Nieves 1992; Blackman et al. 1993; Costin 1991, 2000; Costin and Hagstrum 1995; Feinman et al. 1981; London 1991; Longacre 1991; Longacre et al. 1988; Rice 1989, 1991;
Sinopoli 1988; Stark 1995). Degree of standardization may be assessed through raw material composition, manufacturing techniques, form and dimensions, and surface decoration. Two types of attributes may be distinguished (Costin and Hagstrum 1995): intentional and mechanical. Intentional attributes are controlled by the artisan and include technological, morphological, and stylistic properties. Mechanical attributes are those "which the potter unintentionally introduces into his or her works" (Costin and Hagstrum 1995:622). They relate to motor habits and skill, and, because they are unconscious, they more directly reflect the organization of production. In this regard, metric variability should reflect the number of work units,

Valentine Roux $\boldsymbol{m}$ Laboratoire de Préhistoire et Technologie, CNRS, 92023 Nanterre cedex, France

American Antiquity, 68(4), 2003, pp. 768-782

Copyright $\odot 2003$ by the Society for American Archaeology 
"on the assumption that the amount of variability in these mechanical attributes correlated directly with the number of independent potters or work groups" (Costin and Hagstrum 1995:622). For a large quantity of pottery, the less the variability, the fewer the number of full-time potters.

The inverse correlation between metric variability and rate of production has been partly tested by ethnoarchaeological studies (e.g., Kvamme et al. 1996; Longacre 1999). Statistical results have enabled the authors to differentiate, for aperture and height, between household potters and part-time and/or full-time potters, and for aperture between part-time and full-time potters. The authors conclude that numerous factors (e.g., differences in raw materials, potters' levels of expertise, market demand, manufacturing techniques, local traditions, and types of measurement aids) affect ceramic standardization (see also Arnold and Nieves 1992), and that more effective means of measuring and assessing variability in ceramics would help "untangle relationships between production intensity and product standardization" (Kvamme et al. 1996:125).

With this purpose in mind, we conducted an ethnoarchaeological study to isolate the parameters involved in standardization, as well as to quantify the relationship between intensity of production and degree of standardization. We examine vessels made by Indian and Spanish potters with different rates of production. We then compare results to Filipino data to propose regularities (Gallay 1986) between rate of production and metric variability, taking into account different possible emic conceptions of standardization. Results are applied to archaeological data from Mesopotamia.

\section{Ethnographic Case Studies}

Three ethnographic situations are considered. Two of them are in India, in rural and urban contexts. They are characterized respectively by low- and high-rate ceramic production. These two situations, because they pertain to the same cultural context, will enable us to easily isolate the parameter "intensity of production" and assess its effects on standardization. The third case, in Spain, is in an urban context. This enables us to compare high-rate ceramic production within two different cultural contexts. Moreover, the Spanish example enables us to compare high-rate production using different fashioning techniques: without rotative kinetic energy and with rotative kinetic energy (here, paddle-and-anvil and wheel throwing).

\section{Low-Rate Ceramic Production (India)}

Low-rate ceramic production was studied in the southern part of Andhra Pradesh (A.P.). Four villages, next to Tirupati, were visited within the framework of an ethnoarchaeological survey ${ }^{1}$ (Chavaram Bekam, Alapakam, Kota Aruru and Chapakam). These villages are separated by only 3-10 km. Each of them contains 1,200-2,000 inhabitants and $2-5$ potters. Potters work within the domestic space, in the courtyard or under an awning. There is no warehouse; pots are stored in the house. The firing area is generally located at the outskirts of the village. Potters work throughout the year according to different rhythms. Festival months like January and February represent the peak season, while monsoon months represent the slack season. In most cases, pottery is the only source of income of the potters. Pots are sold by potters' wives, either through patron-client links (the jajmani system) or through barter or trade, within a $3-4 \mathrm{~km}$ radius.

Three types of vessels represent the larger part of production and consumption: kura catti, ralla catti and pedda bana.

Kura catti are vessels for cooking vegetables (for dishes like kura, samba, rasam). Ralla catti are vessels for cooking lentils ( $d a l$ ) and spinach that, once cooked, are ground against the bottom of the vessel with a wooden pestle. Pedda bana are big storage jars where mainly cereals are stored.

All in all, around 6,000 pots are produced each year per potter, out of which, roughly speaking, less than 50 percent are kura catti and ralla catti, and 5 percent are pedda bana. The other products are various cooking, transport, and storage pots of several sizes. The demand is not for strictly standardized vessels, but for a volume that may vary from one family to another depending on the size of the family.

Vessels are fashioned by a combination of wheel throwing and paddling. Pots are first thrown on a pivoted-spoked wheel. Depending on their dimensions, they are thrown off the hump (kura catti) or from a mass of clay whose quantity corresponds to the pot to be thrown (pedda bana). They are detached from the hump or from the wheel with a 
string in such a way that a hole is left at the bottom. Neck and shoulder dimensions do not usually change after this point. The lower part of the body is a thick wall, shaped by subsequent paddling; the paddling process starts when the clay has reached a leather-hard consistency, using stone anvils and wooden paddles. The first task is to close the hole by paddling the pot in a downward direction. Once the bottom is closed, ash is added to the inner lower part of the body that is shaped with a smaller anvil and a lighter paddle. For ralla catti, sand is added to the bottom as an abrasive against which vegetables will be ground. Paddling follows. The big jars are paddled twice. Ash is added during the second paddling. Ash prevents the anvil from sticking to the clay.

The pots receive little decoration. While pots are still on the wheel, horizontal lines are incised with a piece of wood. Once they have dried, pots are covered with a red slip.

\section{High-Rate Ceramic Production}

High-rate ceramic production was studied in North India and in Spain.

In North India, the study was conducted in Uttam Nagar, a suburb of New Delhi with about 200 potter households. Every house has a nuclear or extended family that owns one or two wheels, placed under open shelters, and one kiln located in the courtyard. The clay, conveyed by truck, is stored in the courtyard or in the street, depending on spatial constraints. Pottery manufacture is a full-time activity that takes place even during the monsoon; rains restrict the number of firings but do not stop production.

The different potters interviewed specialize in the manufacture of water jars (ghada or matka) made in three sizes: small (ghadiya), medium (bich ka ghada) and large (bara ghada). All in all, around 15,000 pots are produced each year per potter, of which, roughly speaking, 30 percent are ghadiya, 60 percent are bich ka ghada, and 10 percent are bara ghada.

Pots are fashioned according to the throwing and paddle-and-anvil technique described for Andhra Pradesh pots. However, as is common in Northwest India (Saraswati and Behura 1964), no hole is left at the bottom when the pot is detached from the wheel, which is a pivoted block wheel.

Spanish ceramic workshops have been studied by Arcellin-Pradelle and Laubenheimer (1982, 1985). These workshops are made up of specialized areas, which include the manufacturing area, the drying area, the kiln, and the warehouse. In some cases, the house is part of the workshop area. Two to four potters can work together. Most assistants are not members of the household.

The production of one workshop has been examined in detail and published extensively. It is located in Vall de Uxo, a village in the province of Castellon. It is run by a single potter who carries out the whole manufacturing process. He works intensively (10 hours a day), 11 months a year. Vessels are sold mainly through middlemen. Production includes table and cooking vessels.

Pitchers with flat bottoms are considered here. They are wheel thrown on a kick-wheel. When the clay has reached a leather-hard consistency, the bottom is turned (scraped) on the wheel. The handle is fixed with slurry. The potter makes about 50 pitchers a day. Annual production is approximately 14,000 pitchers.

According to the craftsman, his intention is to make very similar pots; standardization, in his view, indexes the degree of skill.

\section{Analytical Procedure}

To study how rate of production affects metric variability on series of vessels representing a single ceramic type, we examine series of vessels fashioned within low-rate $v s$. high-rate production contexts. Series of vessels made by one potter is a production event and represent a "group." The hypothesis is as follows: if rate of production affects motor habits, then vessels made by high-rate producers will present less intra- and inter-group variability than low-rate producers. Metric indices that may reveal motor habits remain to be defined on the basis of empirical data. A wide range of measures is therefore considered.

\section{Measurements}

Measurements of Andhra Pradesh ceramics include (Figure 1) height, maximum diameter, aperture (rim diameter), thickness of the wall and of the lip, and width of the lip. For the thickness, we took three measures on each side of the pot: two of them relate to the wheel-thrown part, one relates to the paddled part. Thickness and width of the lip were measured on each side of the aperture. These measures 


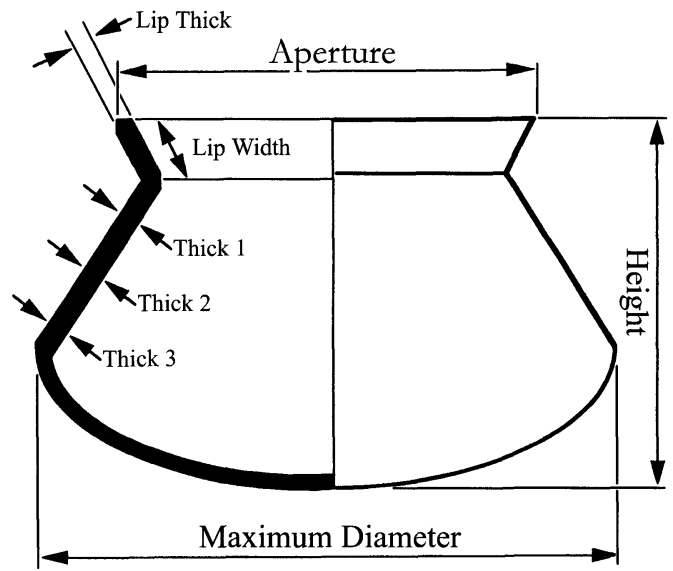

Figure 1. Measurements taken on Andra Pradesh vessels (ralla catti).

enable us to calculate indexes of regularity in the fashioning of the walls and the lip. ${ }^{2}$

Measurement of New Delhi ceramics include height, maximum diameter and aperture (rim diameter).

For Spanish ceramics, measurements taken by Arcellin-Pradelle and Laubenheimer include (Figure 2) (1) maximum diameter, (2) aperture, (3) neck diameter, (4) base diameter, (5) total height, (6) height of the maximum diameter, (7) lip height, (8) lip thickness, (9) handle width, (10) handle thickness, (11) height of the decoration (distance between the bottom and an incised groove), (12) height of the zone that has not been turned (scraped), (13) capacity, and (14) weight.

\section{Data}

In Andhra Pradesh, dimensions were measured on 166 ralla catti, 186 kura catti and 85 pedda bana made by, respectively, 6,7 , and 6 potters.

Three potters (A, B, and G) live in Chavaram Bekam. They are respectively 45,35 , and 32 years old. Two of them (A and B) are brothers-in-law. They live in the same compound.

Two potters (C and D) live in Alapakam. Son and father, they are respectively 30 and 60 years old, and live in the same compound.

One potter $(\mathrm{E})$ lives in Kota Aruru. He is 45 years old.

One potter $(\mathrm{F})$ lives in Chapakam. He is 65 years old.

Except for two series of kura catti, the ceramic vessels were not fired, having been made the day

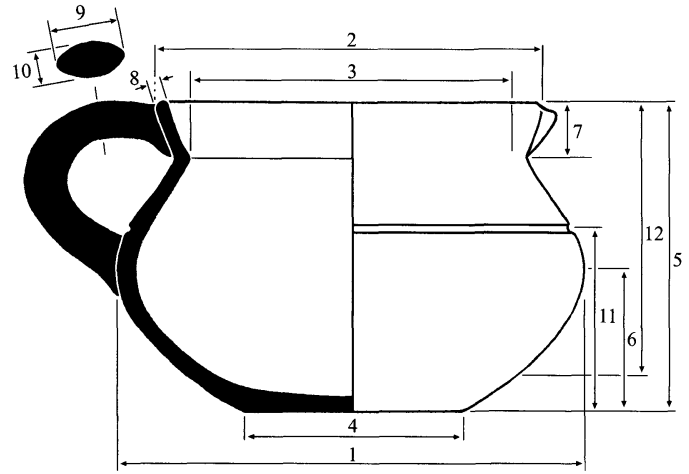

Figure 2. Measurements taken on Spanish vessels. (1) Maximum diameter, (2) aperture, (3) neck diameter, (4) base diameter, (5) total height, (6) maximum diameter height, (7) lip height, (8) lip thickness, (9) handle width, (10) handle thickness, (11) height of the decor (distance between the bottom and an incised groove), and (12) height of the zone which has not been turned.

they were measured, or the day before. The fact that vessels were not fired and not measured the same day does not affect the results. Indeed, all the vessels were measured leather hard, that is to say when the drying shrinkage affecting the volume of a ceramic had already occurred. Moreover, the kura catti data did not reveal any significant difference of values between the fired and unfired series.

In New Delhi, measurements of 180 ghariya were made. These pots are fired and distributed by 6 potters who are, on average, 46 years old (the youngest is 30 and the oldest is 65).

In Spain, 100 fired pitchers were measured. These were made in the course of two days by one potter. Depending on the day of manufacture, they belong to series A or B. Series C includes series A and $\mathrm{B}$.

\section{Indexes of Standardization}

Variability between low-rate and high-rate production is examined by comparing the inter-group variability presented by the two Indian assemblages (Andhra Pradesh vs. New Delhi). Let us recall that a group corresponds to a potter's production. Comparison is justifiable since the fashioning process is the same in both situations.

Inter-group variability has been computed using ANOVA (analysis of variance). As underlined by Kvamme et al. (1996), results obtained by an $F$ test are dependent on an assumption of normality that does not hold most of the time. For this reason, 
we proceeded with a posteriori tests $\left(\mathrm{LSD}^{3}\right.$ [Scheffé] and Games-Howell) that are very robust with populations that are not normally distributed and are useful for comparing heterogeneous variances on small samples.

Variability between low-rate and high-rate production is also examined by comparing the intragroup variability presented by the Indian (Andhra Pradesh and New Delhi) and the Spanish samples. The Spanish material will enable us to test whether the range of values, as observed in the Indian highrate production context, varies according to the technique (from paddle-and-anvil to wheel throwing). Moreover, the Spanish example will enable us to test the variability of ceramics made over the course of two days by the same potter.

Intra-group variability has been calculated on the basis of Coefficient of Variation $(C V) . C V$ is defined as the sample standard deviation divided by the sample mean, multiplied by 100 and expressed as a percentage. It may be considered as the standard statistic in studies of variation and therefore as an excellent measure of standardization (Eerkens and Bettinger 2001).

\section{Results}

The results of these analyses enable us to assess how rate of production affects the metric variability for paddled and wheel-thrown pots.

\section{Inter-Group Variability in Low-Rate Production Contexts}

Inter-group variability exists in low-rate production contexts; ANOVA shows significant differences ( $p$ $<.001$ ) between the series of vessels produced by the different Indian potters from Andhra Pradesh (Figures 3, 4, and 5). Statistical tests (LSD [Scheffé] and Games-Howell) confirm these differences ( $p$ $<.05$ ). These differences hold for height, aperture, and maximum diameter. ${ }^{4}$ They do not hold for the indexes of regularity of wall and of lip (width and thickness).

Pedda bana are produced less frequently than ralla catti and kura catti. However, they are not characterized by inter-individual differences stronger than the ones displayed by the two other classes of vessels.

Aperture is established during wheel throwing and is not modified later by paddling, as are vessel height and maximum diameter. However, contrary
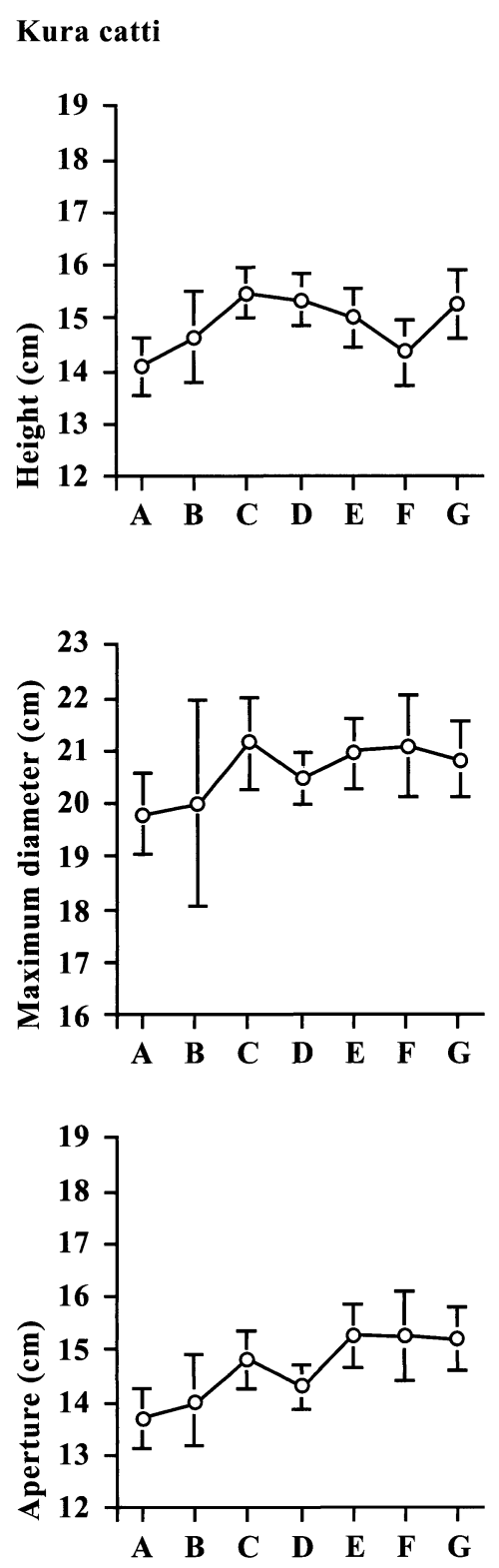

Figure 3. Inter-group differences among Andhra Pradesh potters (A-G) as shown by means and standard deviations of measurements taken on kura catti.

to what we expected, wheel throwing does not produce less variability than the paddle-and-anvil technique.

\section{Inter-Group Variability in High-Rate Production Contexts}

North Indian vessels display inter-group variability as attested on the basis of ANOVA that shows significant differences $(p<.001)$ between ghariya 


\section{Ralla catti}
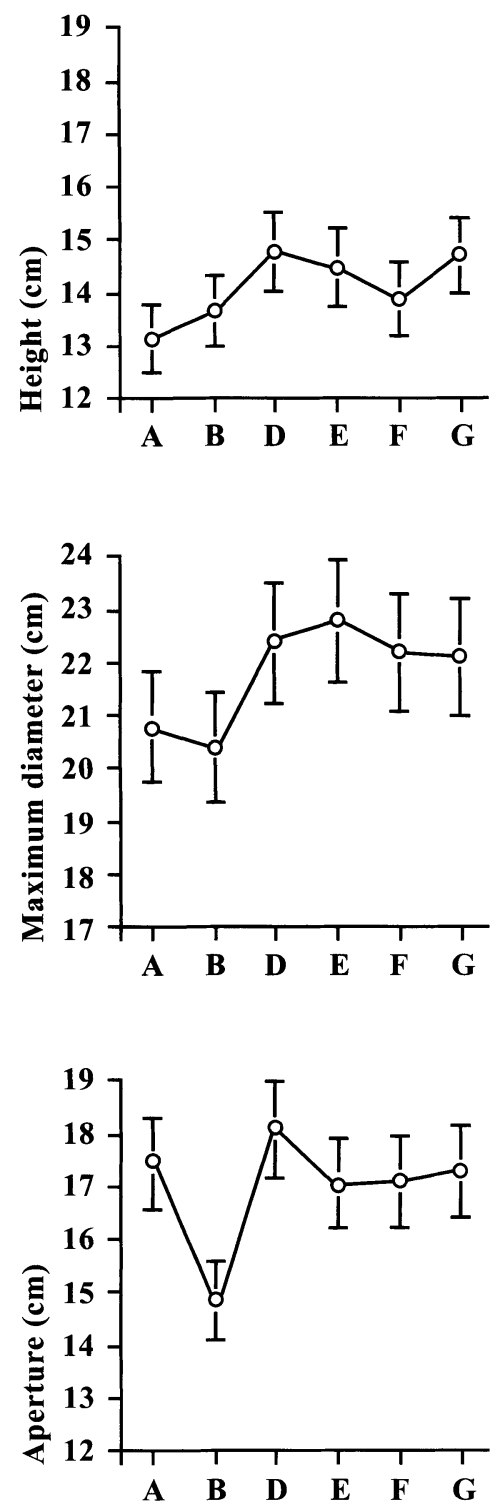

Figure 4. Inter-group differences among Andhra Pradesh potters (A-G) as shown by means and standard deviations of measurements taken on ralla catti.

produced by Delhi potters (Figure 6). Statistical tests (LSD [Scheffé] and Games-Howell) confirm these differences $(p<.05)$. These differences hold for height, aperture, and maximum diameter. ${ }^{5}$

Intra-Group Variability in Low-Rate Production Contexts

The Andhra Pradesh ceramics yield the following

\section{Pedda Bana}
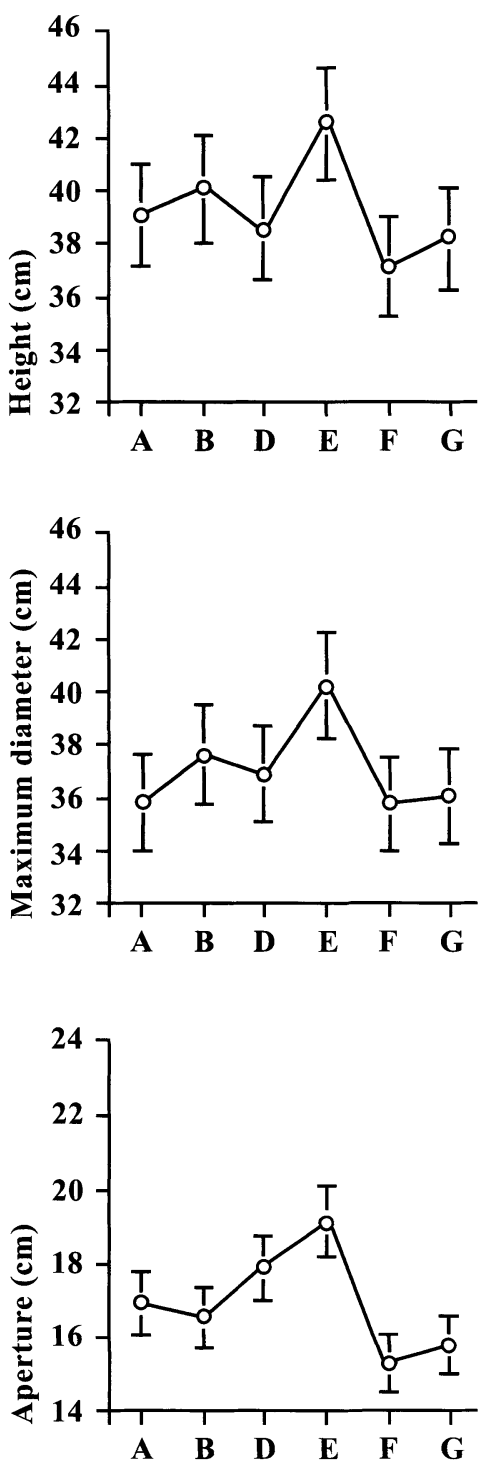

Figure 5. Inter-group differences among Andhra Pradesh potters (A-G) as shown by means and standard deviations of measurements taken on pedda bana.

results: variability in $C V s$ for height, maximum diameter, and aperture is highest for pedda bana. For pedda bana, $C V$ values range from 1.43 to 7.81 percent. For ralla catti, $C V$ values range mainly from 2.01 to 4.70 percent, except for one potter whose $C V$ values range from 6.61 to 7.15 percent. This potter $(\mathrm{F})$ is the oldest ( 65 years old). For kura catti, $C V$ values range mainly from 2.50 to 

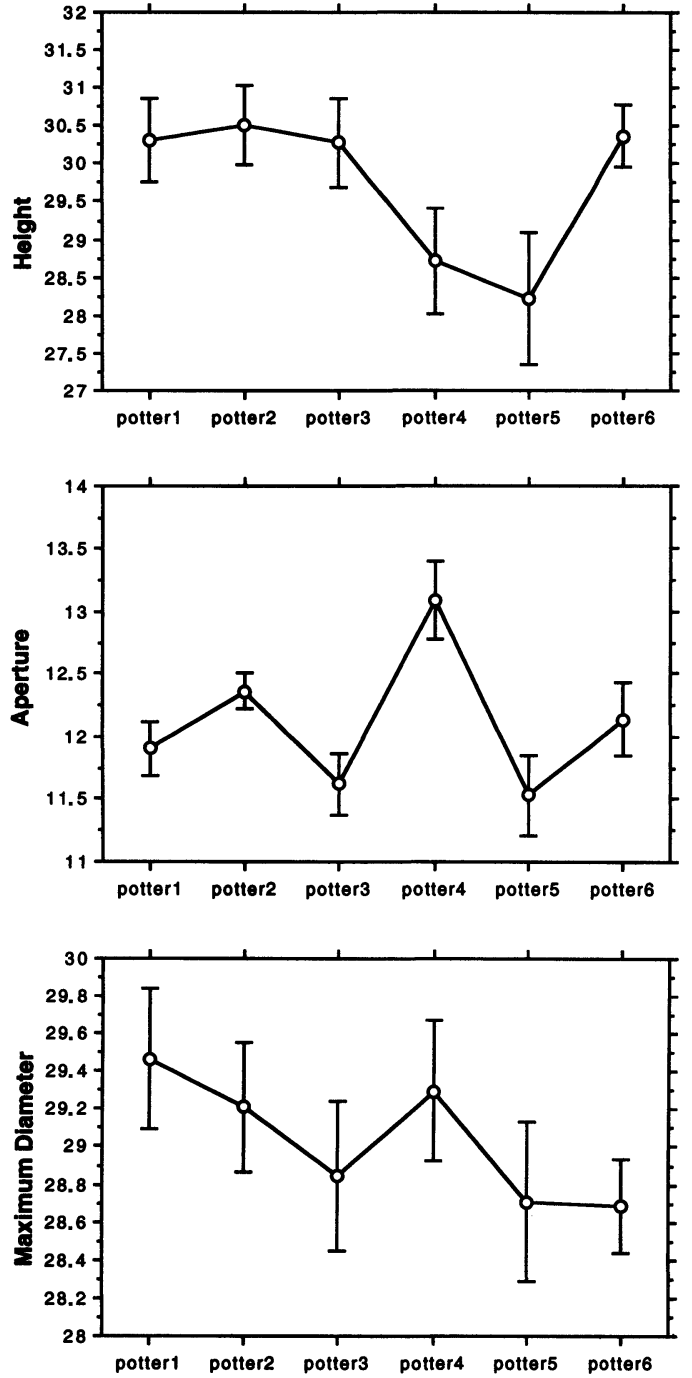

Potters of New Delhi

Figure 6. Inter-group differences among New Delhi potters (1-6) as shown by means and standard deviations of measurements taken on ghariya.

5.54 percent, except for one potter whose $C V$ values range from 5.98 to 9.71 percent (Figure 7). This potter (B), who is 35 years old, is acknowledged to not be as good a potter as his brother-inlaw (A).

Whatever the absolute dimensions, whether height, maximum diameter, or aperture, standard deviations $(S D)$ and $C V$ vary within the same range. Since aperture is obtained by throwing, maximum diameter by paddling, and height by a combination of throwing and paddling, it follows that variation

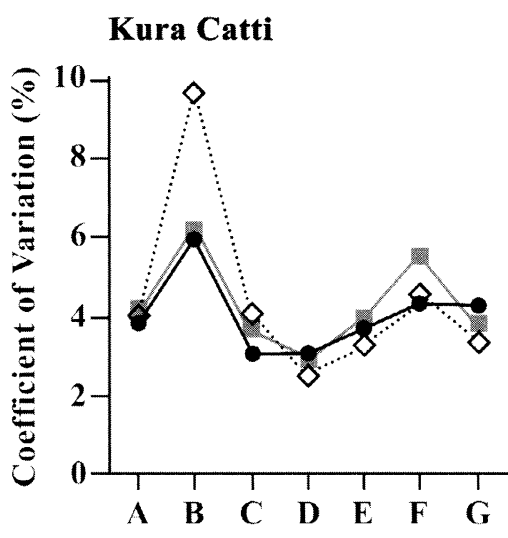

\section{Ralla Catti}
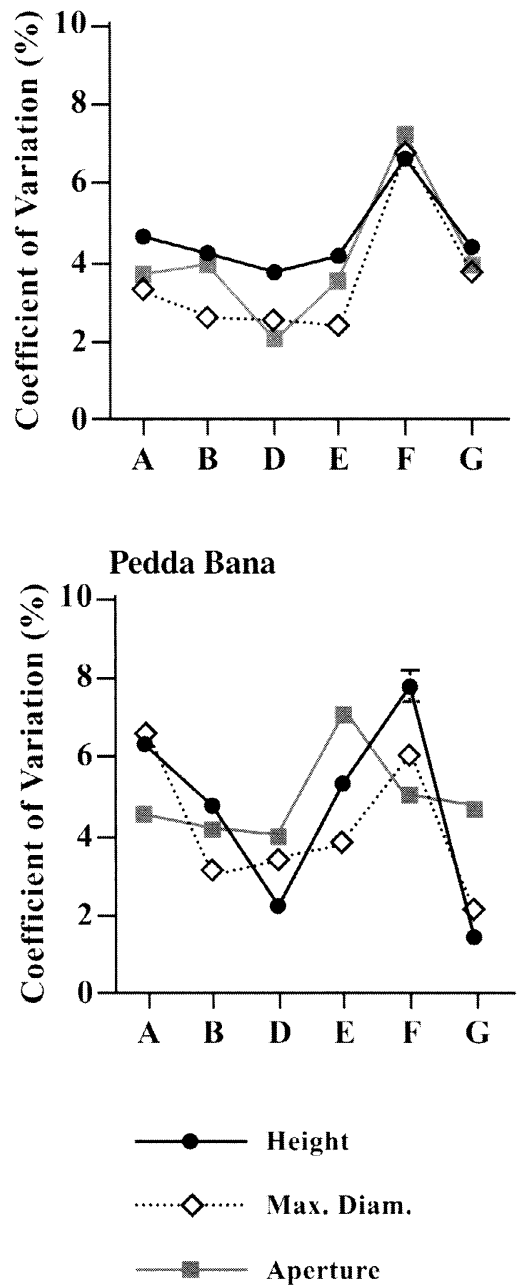

Figure 7. Coefficients of variations (CV) of measurements taken on series of kura catti, ralla catti and pedda bana produced by Andhra Pradesh potters (A-G). 
Table 1. Measurements Taken on the Series of Ralla Catti Produced by Six Potters from Andhra Pradesh.

\begin{tabular}{|c|c|c|c|c|c|c|c|c|}
\hline Potters & Height & $\begin{array}{c}\text { Max. } \\
\text { Diameter }\end{array}$ & Aperture & $\begin{array}{c}\text { Wall } \\
\text { Thick1 }\end{array}$ & $\begin{array}{c}\text { Wall } \\
\text { Thick2 }\end{array}$ & $\begin{array}{c}\text { Wall } \\
\text { Thick3 }\end{array}$ & $\begin{array}{c}\text { Lip } \\
\text { Width }\end{array}$ & $\begin{array}{c}\text { Lip } \\
\text { Thickness }\end{array}$ \\
\hline \multicolumn{9}{|c|}{ Potter A $(n=31)$} \\
\hline Mean $(\mathrm{cm})$ & 13.13 & 20.8 & 17.42 & .41 & .46 & .39 & 1.32 & - \\
\hline$S D$ & .62 & .68 & .64 & .07 & .06 & .09 & .19 & - \\
\hline$C V(\%)$ & 4.7 & 3.29 & 3.68 & 16.22 & 13.54 & 22.76 & 14.57 & - \\
\hline \multicolumn{9}{|c|}{ Potter B $(n=30)$} \\
\hline Mean $(\mathrm{cm})$ & 13.64 & 20.39 & 14.82 & .25 & .34 & .52 & 1.83 & .65 \\
\hline$S D$ & .57 & .54 & .58 & .06 & .08 & .11 & .11 & .17 \\
\hline$C V(\%)$ & 4.19 & 2.62 & 3.91 & 23.93 & 24.41 & 21.75 & 6.26 & 25.65 \\
\hline \multicolumn{9}{|c|}{ Potter D $(n=30)$} \\
\hline Mean $(\mathrm{cm})$ & 14.78 & 22.38 & 18.05 & .40 & .49 & .54 & 1.76 & 1.4 \\
\hline$S D$ & .55 & .56 & .36 & .06 & .07 & .07 & .11 & .15 \\
\hline$C V(\%)$ & 3.75 & 2.51 & 2.01 & 14.9 & 13.58 & 13.48 & 6.44 & 10.5 \\
\hline \multicolumn{9}{|c|}{ Potter E $(n=30)$} \\
\hline Mean $(\mathrm{cm})$ & 14.47 & 22.79 & 17.02 & .26 & .31 & .44 & 1.73 & .53 \\
\hline$S D$ & .6 & .56 & .61 & .05 & .04 & .06 & .09 & .07 \\
\hline$C V(\%)$ & 4.16 & 2.45 & 3.58 & 21.01 & 13.66 & 14.08 & 5.47 & 12.39 \\
\hline \multicolumn{9}{|c|}{ Potter F $(n=18)$} \\
\hline Mean $(\mathrm{cm})$ & 13.84 & 22.23 & 17.06 & .34 & .38 & .56 & 1.72 & .94 \\
\hline$S D$ & .91 & 1.5 & 1.22 & .05 & .06 & .07 & .09 & .14 \\
\hline$C V(\%)$ & 6.61 & 6.73 & 7.15 & 13.98 & 16.95 & 12.38 & 5.38 & 14.68 \\
\hline \multicolumn{9}{|c|}{ Potter G $(n=27)$} \\
\hline Mean $(\mathrm{cm})$ & 14.68 & 22.11 & 17.25 & .41 & .39 & .47 & 1.7 & .74 \\
\hline$S D$ & .64 & .84 & .67 & .08 & .06 & .07 & .09 & .13 \\
\hline$C V(\%)$ & 4.37 & 3.79 & 3.87 & 18.55 & 15.46 & 14.19 & 5.16 & 17.21 \\
\hline
\end{tabular}

in dimension does not seem to depend on the fashioning technique.

Amplitude of $C V$ varies, for some potters, from one category of vessel to the next. The same potter can present low $C V$ values on pedda bana, and higher $C V$ values on kura catti, or low $C V$ values on kura catti and higher $C V$ values on ralla catti.

For the three types of vessels, thickness of walls shows very high intra-group variations, reflected in $C V$ values that can reach 25 percent (Tables $1,2,3$ ).

$C V$ values for lip thickness and width range mostly from 4 to 8 percent. However, some vessel groups show high intra-individual variation (Tables $1,2,3)$.

When considering the standard deviations and $C V$ values of each type of vessel, all potters pooled, it appears that, for height, maximum diameter and aperture, $C V$ values range from 5 to 9 percent (Table 4). There is a cumulative effect, also called "cumulative blurring" (Blackman et al. 1993) that makes these pooled $C V$ values higher than those for each potter.

\section{Intra-Group Variability in High-Rate Production Contexts}

In Uttam Nagar (New Delhi), variability within potters' production is less than in Andhra Pradesh. Except for one variable (height of the jars made by potter 5), all the $C V$ values are less than 3 percent (Table 5). Maximum diameter presents the lowest values, ranging from .87 to 1.40 percent. $C V$ values of aperture range from 1.19 to 2.83 percent. $C V$ values of height range from 1.40 to 3.19 percent.

When pooling the potters, height, maximum diameter and aperture present $C V \mathrm{~s}$ that range from 1 to 5 percent (Table 6 ). Once again the cumulative effect results in $C V$ values higher than those for each individual potter.

In Spain, whatever the series considered (A, B or $\mathrm{C})$, the dimensions that vary least are height, 
Table 2. Measurements Taken on the Series of Kura Catti Produced by Seven Potters from Andhra Pradesh.

\begin{tabular}{|c|c|c|c|c|c|c|c|c|}
\hline Potters & Height & $\begin{array}{c}\text { Max. } \\
\text { Diameter } \\
\end{array}$ & Aperture & $\begin{array}{c}\text { Wall } \\
\text { Thick1 }\end{array}$ & $\begin{array}{c}\text { Wall } \\
\text { Thick2 }\end{array}$ & $\begin{array}{c}\text { Wall } \\
\text { Thick3 }\end{array}$ & $\begin{array}{c}\text { Lip } \\
\text { Width } \\
\end{array}$ & $\begin{array}{c}\text { Lip } \\
\text { Thickness }\end{array}$ \\
\hline \multicolumn{9}{|c|}{ Potter A $(n=30)$} \\
\hline Mean $(\mathrm{cm})$ & 14.11 & 19.82 & 13.7 & .3 & .53 & .4 & 2.73 & 1.0 \\
\hline$S D$ & .55 & .78 & .57 & .08 & .10 & .08 & .24 & .14 \\
\hline$C V(\%)$ & 3.87 & 3.94 & 4.19 & 25.95 & 18.06 & 20.85 & 8.66 & 13.81 \\
\hline \multicolumn{9}{|c|}{ Potter B $(n=30)$} \\
\hline Mean $(\mathrm{cm})$ & 14.66 & 20.01 & 14.04 & .37 & .38 & .44 & 2.98 & 1.18 \\
\hline$S D$ & .88 & 1.94 & .87 & .07 & .07 & .06 & .24 & .110 \\
\hline$C V(\%)$ & 5.98 & 9.71 & 6.21 & 18.0 & 18.23 & 13.9 & 7.88 & 9.39 \\
\hline \multicolumn{9}{|c|}{ Potter C $(n=11)$} \\
\hline Mean (cm) & 15.48 & 21.17 & 14.82 & .30 & .55 & .45 & 2.77 & 1.1 \\
\hline$S D$ & .45 & .86 & .55 & .07 & .09 & .06 & .18 & .10 \\
\hline$C V(\%)$ & 2.88 & 4.06 & 3.68 & 22.59 & 16.49 & 13.1 & 6.41 & 9.5 \\
\hline \multicolumn{9}{|c|}{ Potter $\mathrm{D}(n=31)$} \\
\hline Mean (cm) & 15.34 & 20.49 & 14.3 & .30 & .52 & .52 & 2.58 & 1.07 \\
\hline$S D$ & .47 & .51 & .43 & .04 & .07 & .07 & .11 & .12 \\
\hline$C V(\%)$ & 3.08 & 2.5 & 3.0 & 14.66 & 14.12 & 14.12 & 4.13 & 11.44 \\
\hline \multicolumn{9}{|c|}{ Potter $\mathrm{E}(n=30)$} \\
\hline Mean $(\mathrm{cm})$ & 15.03 & 20.96 & 15.23 & .21 & .36 & .39 & 2.74 & 1.01 \\
\hline$S D$ & .56 & .68 & .59 & .06 & .05 & .04 & .11 & .08 \\
\hline$C V(\%)$ & 3.71 & 3.26 & 3.9 & 29.48 & 12.84 & 10.15 & 4.14 & 7.95 \\
\hline \multicolumn{9}{|c|}{ Potter F $(n=24)$} \\
\hline Mean (cm) & 14.37 & 21.09 & 15.28 & .27 & .34 & .37 & 2.25 & 1.12 \\
\hline$S D$ & .63 & .96 & .85 & .06 & .08 & .06 & .13 & .09 \\
\hline$C V(\%)$ & 4.38 & 4.55 & 5.54 & 23.24 & 22.62 & 15.39 & 5.85 & 7.88 \\
\hline \multicolumn{9}{|c|}{ Potter $\mathrm{G}(n=30)$} \\
\hline Mean $(\mathrm{cm})$ & 15.27 & 20.85 & 15.22 & .29 & .48 & .49 & 2.14 & .89 \\
\hline$S D$ & .65 & .70 & .58 & .05 & .08 & .06 & .15 & .07 \\
\hline$C V(\%)$ & 4.26 & 3.35 & 3.82 & 18.05 & 16.17 & 11.74 & 7.01 & 7.44 \\
\hline
\end{tabular}

maximum diameter, and aperture (rim and neck diameter). Their $C V$ values range from 1.4 to 2.9 percent (Table 7). Such a variation in the precision of the dimensions has been observed for the production of six other workshops located in distant villages. The other dimensions present a greater degree of variability (higher $C V$ ).

The standard deviation of series $A$ is smaller than that of series $B$, which means that the potter made vessels with a higher degree of variability on day B than on day A. When statistically comparing the means (Aspin Welsh test), it appears that means distinguish the two groups for the following parameters: capacity, weight, height of maximum diameter, and height of the decoration. They are the parameters with the higher $C V$.

\section{Discussion}

We can now examine whether rate of production affects motor habits and consequently degree of standardization.

Our results suggest that the series of vessels considered here present different degrees of standardization resulting from differing rates of production. High-rate ceramic production is less variable than low-rate production (Tables 4,6 , and 7). However, even with high rates of production, work units may be distinguished through metric variables as exemplified by the inter-group analysis of New Delhi potters (Figure 6).

Variability of ceramic assemblages is best expressed by $C V$ s that are placed here along a continuum of variation from .87 to 25 percent. The 
Table 3. Measurements Taken on Series of Pedda Bana Produced by Six Potters from Andhra Pradesh.

\begin{tabular}{|c|c|c|c|c|c|c|c|c|}
\hline Potters & Height & $\begin{array}{c}\text { Max } \\
\text { Diameter }\end{array}$ & Aperture & $\begin{array}{c}\text { Wall } \\
\text { Thick1 }\end{array}$ & $\begin{array}{c}\text { Wall } \\
\text { Thick2 }\end{array}$ & $\begin{array}{c}\text { Wall } \\
\text { Thick3 }\end{array}$ & $\begin{array}{c}\text { Lip } \\
\text { Width }\end{array}$ & $\begin{array}{c}\text { Lip } \\
\text { Thickness }\end{array}$ \\
\hline \multicolumn{9}{|c|}{ Potter A $(n=12)$} \\
\hline Mean $(\mathrm{cm})$ & 39.09 & 35.68 & 16.94 & .40 & .48 & .42 & 4.12 & 1.69 \\
\hline$S D$ & 2.45 & 2.34 & .77 & .08 & .08 & .09 & .25 & .14 \\
\hline$C V(\%)$ & 6.27 & 6.56 & 4.55 & 20.06 & 15.7 & 21.77 & 6.11 & 8.15 \\
\hline \multicolumn{9}{|c|}{ Potter B $(n=16)$} \\
\hline Mean $(\mathrm{cm})$ & 40.08 & 37.48 & 16.56 & .44 & .69 & .52 & 4.35 & 1.78 \\
\hline$S D$ & 1.90 & 1.17 & .70 & .07 & .11 & .08 & .21 & .21 \\
\hline$C V(\%)$ & 4.75 & 3.11 & 4.20 & 15.06 & 16.13 & 15.72 & 4.85 & 12.02 \\
\hline \multicolumn{9}{|c|}{ Potter D $(n=16)$} \\
\hline Mean $(\mathrm{cm})$ & 38.58 & 36.74 & 17.91 & .55 & .80 & .69 & 1.83 & 1.14 \\
\hline$S D$ & .84 & 1.24 & .71 & .08 & .08 & .08 & .10 & .10 \\
\hline$C V(\%)$ & 2.17 & 3.38 & 3.96 & 14.19 & 10.21 & 11.11 & 5.54 & 8.43 \\
\hline \multicolumn{9}{|c|}{ Potter E $(n=15)$} \\
\hline Mean $(\mathrm{cm})$ & 42.58 & 40.11 & 19.15 & .43 & .55 & .55 & 3.58 & 1.46 \\
\hline$S D$ & 2.25 & 1.55 & 1.35 & .09 & .07 & .05 & .16 & .10 \\
\hline$C V(\%)$ & 5.29 & 3.86 & 7.04 & 21.18 & 11.9 & 9.94 & 4.50 & 6.75 \\
\hline \multicolumn{9}{|c|}{ Potter F $(n=13)$} \\
\hline Mean $(\mathrm{cm})$ & 37.18 & 35.61 & 15.35 & .48 & .51 & .46 & 4.44 & 1.78 \\
\hline$S D$ & 2.9 & 2.16 & .77 & .09 & .07 & .11 & .33 & .13 \\
\hline$C V(\%)$ & 7.81 & 6.05 & 5.04 & 17.96 & 13.33 & 23.05 & 7.33 & 7.18 \\
\hline \multicolumn{9}{|c|}{ Potter $\mathrm{G}(n=13)$} \\
\hline Mean $(\mathrm{cm})$ & 38.21 & 35.93 & 15.8 & .47 & .73 & .53 & 3.44 & 1.44 \\
\hline$S D$ & .55 & .77 & .74 & .06 & .08 & .07 & .17 & .09 \\
\hline$C V(\%)$ & 1.43 & 2.14 & 4.7 & 13.44 & 10.28 & 12.48 & 4.97 & 6.05 \\
\hline
\end{tabular}

minimum $C V$ is below 1.7 percent, which is the $C V$ value derived from the Weber fraction ${ }^{6}$ (Eerkens and Bettinger 2001), although no automation or independent standard was used in this case. Here, we assume that it is possible to obtain such high degrees of standardization given a high degree of motor expertise acquired through an optimal perception-action ongoing cycle (Bril et al. 2000).

Height, maximum diameter, and aperture are the variables most likely to vary according to motor habits. Lips are stylistic features that allow potters to express themselves as they please. In Spain, the variation in the base diameter could be related to the absence of visual reference when manufacturing the base in the course of the hollowing operation. Variation in height of decoration and turning zone corresponds to the fact that they are secondary attributes that do not contribute to the general shape of the pot.

The forming technique does not affect variability of ceramic assemblages. This result has already been observed (e.g., Benco 1988) although some ethnographic cases tend to show the opposite (Arnold and Nieves 1992). It can be considered robust since we could isolate the technical factor by analyzing pots made according to different

Table 4. Measurements Taken on the Series of Vessels Produced by the Potters from Andhra Pradesh.

\begin{tabular}{lrrr}
\hline Type of vessel & Height & Max. Diameter & Aperture \\
\hline Ralla catti $(\mathrm{n}=166)$ & & & \\
Mean $(\mathrm{cm})$ & 14.1 & 21.74 & 16.93 \\
SD & .88 & 1.19 & 1.24 \\
CV $(\%)$ & 6.27 & 5.46 & 7.35 \\
& & & \\
Kura catti $(\mathrm{n}=174)$ & & & \\
Mean $(\mathrm{cm})$ & 14.81 & 20.52 & 14.61 \\
SD & .78 & 1.13 & .91 \\
CV $(\%)$ & 5.23 & 5.52 & 6.24 \\
& & & \\
Pedda bana $(\mathrm{n}=84)$ & & & \\
Mean $(\mathrm{cm})$ & 39.37 & 37.03 & 17.02 \\
SD & 2.58 & 2.21 & 1.54 \\
CV $(\%)$ & 6.56 & 5.97 & 9.07 \\
\hline
\end{tabular}


Table 5. Measurements Taken on the Series of Vessels Produced by the Six Potters from Uttam Nagar (New Delhi).

\begin{tabular}{|c|c|c|c|}
\hline Potters & Height & $\begin{array}{c}\text { Maximum } \\
\text { Diameter }\end{array}$ & Aperture \\
\hline \multicolumn{4}{|c|}{ Potter $1(n=30)$} \\
\hline Mean $(\mathrm{cm})$ & 30.36 & 29.49 & 11.9 \\
\hline$S D$ & .58 & .36 & .22 \\
\hline$C V(\%)$ & 1.9 & 1.22 & 1.87 \\
\hline \multicolumn{4}{|c|}{ Potter $2(n=30)$} \\
\hline Mean $(\mathrm{cm})$ & 30.51 & 29.19 & 12.36 \\
\hline$S D$ & .48 & .32 & .15 \\
\hline$C V(\%)$ & 1.56 & 1.08 & 1.19 \\
\hline \multicolumn{4}{|c|}{ Potter $3(n=30)$} \\
\hline Mean $(\mathrm{cm})$ & 30.3 & 28.82 & 11.64 \\
\hline$S D$ & .61 & .40 & .26 \\
\hline$C V(\%)$ & 2.01 & 1.40 & 2.25 \\
\hline \multicolumn{4}{|c|}{ Potter $4(n=30)$} \\
\hline Mean $(\mathrm{cm})$ & 28.72 & 29.3 & 13.09 \\
\hline$S D$ & .69 & .36 & .31 \\
\hline$C V(\%)$ & 2.41 & 1.24 & 2.34 \\
\hline \multicolumn{4}{|c|}{ Potter $5(n=30)$} \\
\hline Mean $(\mathrm{cm})$ & 28.19 & 28.74 & 11.52 \\
\hline$S D$ & .90 & .37 & .33 \\
\hline$C V(\%)$ & 3.19 & 1.30 & 2.83 \\
\hline \multicolumn{4}{|c|}{ Potter $6(n=30)$} \\
\hline Mean $(\mathrm{cm})$ & 30.37 & 28.69 & 12.14 \\
\hline$S D$ & .42 & .25 & .29 \\
\hline$C V(\%)$ & 1.40 & .87 & 2.41 \\
\hline
\end{tabular}

techniques (wheel throwing $v s$. paddle-and-anvil).

In Andra Pradesh, there is a tendency for the biggest pots to be less standardized than smaller pots. This tendency has been observed elsewhere (see in particular Benco 1988). It may be that errors in estimating object size increase linearly with the magnitude or size of the intended end product (e.g., Coren et al. 1994 cited in Eerkens and Bettinger 2001:494). Another explanation could be that the biggest pots are produced in smaller quantities and, therefore, that motor habits are less practiced than those for smaller pots. Therefore, metric comparisons should take size classes into account (as underlined also by Stark 1995).

Skill may affect the range of variability. A skill may be defined as the capacity to reach a goal through use of the resources in one's environment (Bril et al. 2000). This capacity may vary from one person to the other, as shown by the Andhra Pradesh
Table 6. Measurements Taken on the Series of Vessels Produced by the Potters from Uttam Nagar (New Delhi).

\begin{tabular}{lrcr}
\hline Ghariya $(n=180)$ & Height & Max. Diameter & Aperture \\
\hline Mean $(\mathrm{cm})$ & 29.74 & 29.04 & 12.11 \\
SD & 1.12 & .47 & .59 \\
$C V(\%)$ & 3.77 & 1.61 & 4.85 \\
\hline
\end{tabular}

potters, among whom some, of the same age, have the same amount of experience. Metric data from San Nicolas in the northern Philippines (Longacre 1999) support this result. Pots produced by the lessskilled potter show greater metrical variation.

The different results obtained for Indian and Spanish pottery can be compared with those from the Philippines. The hypothesis is that if motor habits determine degree of standardization, then we should have, for the three different cultures (Indian, Spanish, Filipino), the same range of metric variability for series of vessels produced within the same range of production (low-rate vs. high-rate production). In other words, intercultural comparison should enable us to assess how ceramic variability may be affected by different emic conceptions of standardization. In Andhra Pradesh, the size-class definition is a function of the size of the family that will use the vessels. In the Philippines, the size classes are based on vessel volume, reckoned through the chupa (ca. $100 \mathrm{ml}$ ) (Kvamme et al. 1996). In Spain, standardization indexes degree of skill and the potter's intention is to make very similar pots, in contrast to Uttam Nagar's potters, whose vessel measurements respond to market-oriented norms. In the Indian and Spanish contexts, all potters pooled, high-rate production yielded ceramic assemblages whose $C V$ values are less than 5 percent, whereas low-rate production yielded ceramic assemblages whose $C V$ values range from 5 to 9 percent. These results are slightly different from the ones obtained in the Philippines (Kvamme et al. 1996). In the Philippines, all potters pooled, the high-rate production (Paradijon, full-time potter specialists) presents $C V$ values that range from 4.3 to 6.92 percent, whereas low-rate production (Dalupa, part-time potter specialists) presents $C V$ s ranging from 4.06 to 5.56 percent. The least-specialized potters (Dangtalan, household use, and restricted exchange) produce ceramics whose $C V$ values range from 6.27 to 8.34 percent. Paradijon and Dalupa ceramics differentiate on aperture only (B-F test, $p=.0482$ ) whereas Dalupa 
Table 7. Measurements Taken on the Series of Pitchers Produced by One Potter in the Course of Two Days.

\begin{tabular}{|c|c|c|c|c|}
\hline Measurements & Series & Mean $(\mathrm{mm})$ & $S D$ & $C V(\%)$ \\
\hline \multirow[t]{3}{*}{ Maximum diameter } & A & 121.1 & 1.7 & 1.4 \\
\hline & B & 120.2 & 2.4 & 2.0 \\
\hline & $\mathrm{C}$ & 121.0 & 2.1 & 1.7 \\
\hline \multirow[t]{3}{*}{ Aperture } & $\mathrm{A}$ & 98.9 & 2.1 & 2.2 \\
\hline & $\mathrm{B}$ & 100.1 & 2.4 & 2.4 \\
\hline & $\mathrm{C}$ & 100.1 & 2.6 & 2.5 \\
\hline \multirow[t]{3}{*}{ Neck diameter } & A & 82.7 & 1.9 & 2.3 \\
\hline & $\mathrm{B}$ & 80.9 & 2.2 & 2.6 \\
\hline & $\mathrm{C}$ & 82.1 & 2.2 & 2.7 \\
\hline \multirow[t]{3}{*}{ Base diameter } & A & 49.6 & 2.6 & 5.7 \\
\hline & $\mathrm{B}$ & 50.4 & 2.2 & 4.4 \\
\hline & $\mathrm{C}$ & 50.0 & 2.3 & 4.6 \\
\hline \multirow[t]{3}{*}{ Total height } & A & 78.8 & 2.1 & 2.6 \\
\hline & B & 80.4 & 2.2 & 2.6 \\
\hline & $\mathrm{C}$ & 79.3 & 2.4 & 2.9 \\
\hline \multirow{3}{*}{$\begin{array}{l}\text { Maximum diam. } \\
\text { height }\end{array}$} & A & 40.3 & 1.8 & 4.4 \\
\hline & B & 40.6 & 2.1 & 5.1 \\
\hline & $\mathrm{C}$ & 41.1 & 1.9 & 3.7 \\
\hline \multirow[t]{3}{*}{ Lip height } & A & 13.9 & .9 & 6.4 \\
\hline & B & 14.4 & 6 & 4.3 \\
\hline & $\mathrm{C}$ & 14.4 & .7 & 4.9 \\
\hline \multirow[t]{3}{*}{ Lip thickness } & A & 5.0 & .1 & 2.0 \\
\hline & B & 5.9 & .3 & 6.0 \\
\hline & $\mathrm{C}$ & 5.0 & .2 & 4.8 \\
\hline \multirow[t]{3}{*}{ Handle width } & A & 17.5 & .7 & 4.0 \\
\hline & B & 17.2 & .5 & 3.0 \\
\hline & $\mathrm{C}$ & 17.4 & .8 & 2.8 \\
\hline \multirow[t]{3}{*}{ Handle thickness } & A & 10.5 & .5 & 4.7 \\
\hline & B & 9.8 & .5 & 5.1 \\
\hline & $\mathrm{C}$ & 10.2 & .6 & 6.0 \\
\hline \multirow[t]{3}{*}{ Height of the decor } & A & 46.9 & 2.3 & 4.9 \\
\hline & $\mathrm{B}$ & 45.9 & 3.1 & 6.8 \\
\hline & $\mathrm{C}$ & 46.1 & 2.9 & 6.1 \\
\hline \multirow{3}{*}{$\begin{array}{l}\text { Height of the } \\
\text { non-turned zone }\end{array}$} & A & 56.4 & 5.2 & 9.2 \\
\hline & B & 51.8 & 5.8 & 11.2 \\
\hline & $\mathrm{C}$ & 55.2 & 6.0 & 10.0 \\
\hline \multirow[t]{3}{*}{ Capacity } & A & 489.6 & 25.1 & 5.1 \\
\hline & $\mathrm{B}$ & 490.2 & 18.5 & 6.2 \\
\hline & $\mathrm{C}$ & 492.1 & 28.3 & 15.7 \\
\hline \multirow[t]{3}{*}{ Weight } & A & 353.2 & 14.5 & 4.1 \\
\hline & B & 348.5 & 17.4 & 5.0 \\
\hline & $\mathrm{C}$ & 352.5 & 16.8 & 4.7 \\
\hline
\end{tabular}

Note: Series A $(n=50)$ and B $(n=50)$ were made over two days. Series C pools series A and B. Data from ArcellinPradelle and Laubenheimer (1985)

and Dangtalan ceramics differentiate on aperture and height (B-F test, $p=.008, p=.0003)$ (Kvamme et al. 1996). The three communities employ a combination of coil-and-scrape and paddle-and-anvil techniques to fashion their pots.

These observations suggest, first, that smallscale production does develop motor habits that enable potters to produce standardized series of vessels comparable to those made by high-rate producers. This point is supported by the San Nicolas data published by Longacre (1999). Series of water jars $(62,36,25$, and 20 pots made respectively by four potters) vary between about 3 and 4 percent metrically. Their annual production is comparable to that achieved by the Andhra Pradesh potters (Longacre indicates that they make 100 pots per week when it is not raining). Small-scale production refers here to annual production of a few thousands pots. It has to be distinguished from very small-scale production whose metric variability is much higher. The Kalinga pottery varies about 12 percent (Longacre 1999). Such variation is comparable to the variation observed in Papua and Amazonia for very low production (Stark 1995).

Second, emic conceptions of class sizes may induce a certain variability, which is why $C V$ values do not range the same way from one culture to the other, despite similar rates of production (as observed also by Longacre 1999).

Third, in a cumulative-effect situation, no smallscale ceramic assemblage presents at least two variables with $C V$ values lower than 3 percent.

To summarize, the ethnographic data presented here suggest that ceramic assemblages presenting $C V$ values from 3 to 6 percent are quite ambiguous. They may result from large-scale as well as small-scale production. Ceramic assemblages presenting $C V$ values from 6 to 9 percent may belong to small-scale as well as very small-scale production. Ceramic assemblages presenting at least two variables with $\mathrm{CV}$ values below 3 percent point to high-scale production (Figure 8).

These ceramic assemblages are made up of fewer than 10 production events (i.e., let us recall that a production event corresponds to a potter's production). In the future, more assemblages representing more numerous production events should be analyzed. Indeed, we have seen that the more we pool potters together, the greater the cumulative effect that plays on the $C V$ values. This cumulative effect should be amplified if assemblages are made up of production events achieved over a few centuries, or else multiple production events.

Finally, let us recall that large-scale production is achieved by full-time specialists, whereas lowscale production may be achieved either by fulltime or part-time specialists, or even by the least-specialized potters in a community. 


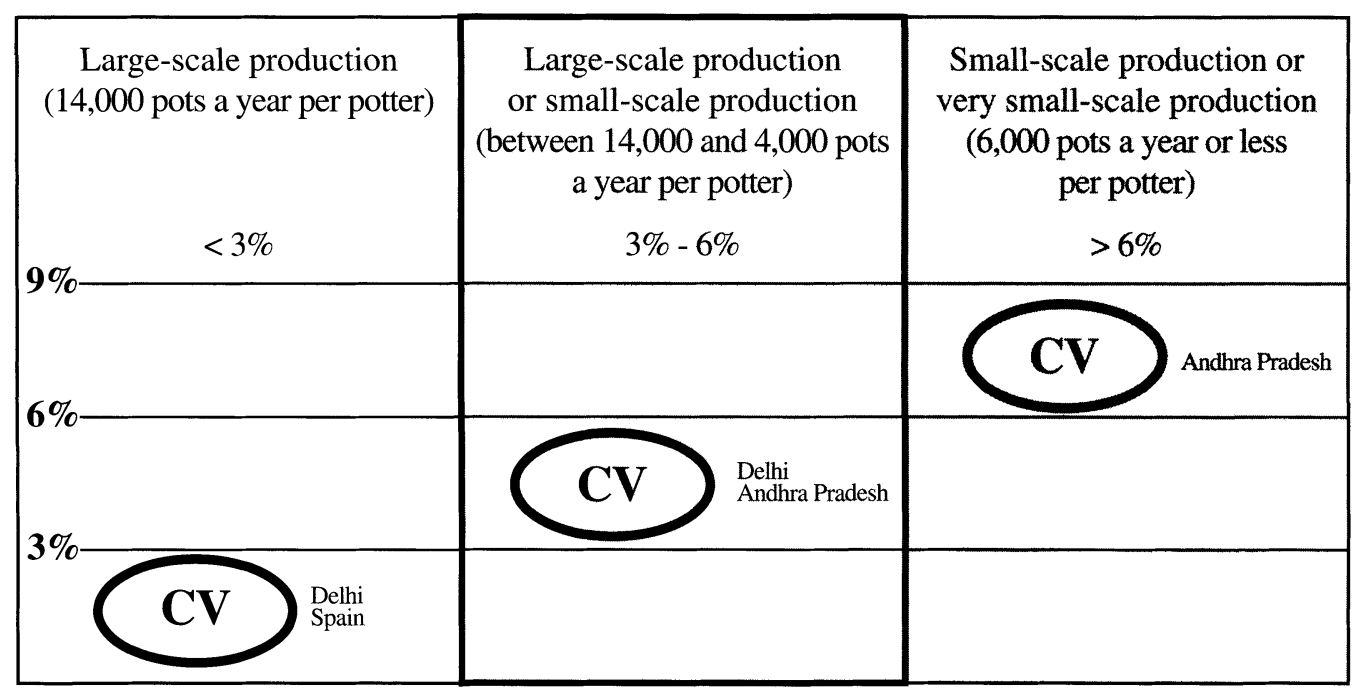

Figure 8. Quantifying rate of production by reference to ceramic assemblages made up of less than 10 production events.

\section{Application To Archaeological Data}

Let us now apply our results to archaeological data. We consider the "open-simple-rim" fine ware bowls that had become one of the most characteristic ceramic forms by 2200 B.C. at Tell Leilan and numerous other sites in Northern Mesopotamia. As outlined by Blackman et al. (1993), they offer the rare opportunity to examine the notion of standardization since large waster stacks have been recovered in the eastern part of the Leilan lower town (Period IIb). A portion of the stacks, containing 27 whole bowls and bowl fragments, was brought to United States and examined by Blackman et al. (1993). According to their results, standardized procedures were followed at every step of the bowl-production process. Chemical analysis of the bowls in the waster stack shows a remarkably high degree of homogeneity in the chemical composition of the constituent clays. Concerning vessel dimensions, five measurements were made: rim diameter, wall thickness $1 \mathrm{~cm}$ below the rim, vessel height, base diameter, and maximum basal thickness. According to Blackman et al. (1993), these bowls show a high degree of standardization since $C V$ values are less than 10 percent. From this, they conclude that "metric data from the Leilan wasters show a level of homogeneity consistent with expectations for specialized mass production of utilitarian goods" (Blackman et al. 1993:73).
Tell Leilan bowls are supposed to be a single production event. If we compare Tell Leilan bowls with Indian, Spanish, and Filipino vessels in terms of standard deviation and $C V$, it appears that we are dealing with a weakly standardized production system: $C V$ values of rim diameters are 9.19 percent and $C V$ values of heights are 4.4 percent. These $C V$ values, which are not affected by any cumulative effect, are high compared to our ethnographic reference points. They do not correspond to so-called large-scale production. They may reflect small-scale production, which means that, even if they were made by specialists (as attested by the skills required for their fashioning; see Roux and Corbetta 1989), the rate of production may not have been so high (Figure 8).

The low degree of standardization that appears in this production is quite consistent with the variability measured on a second series of open-simple-rim bowls recovered from domestic refuse contexts (Leilan, Period IIb). This second series could have been produced over 200 years. $C V$ values reach 18 percent. Blackman et al. (1993) interpret this variability in terms of noncentralized production; i.e., multiple workshops during period IIb. According to our ethnographic data, the cumulative effect of intra- and inter-group variability should not be underestimated (as underlined also by Blackman et al. 1993). In the case of the second series of bowls from Tell Leilan, the 18 
percent $C V$ values could be the result of a cumulative effect over 200 years and correspond to vessels whose degree of variability, for a single production event, could not have exceeded 9 percent. The variability of the two series of bowls may therefore be highly comparable (as suggested also by Blackman et al. 1993:74) and interpreted in terms of similar rates of production.

\section{Conclusion}

In this paper, we have examined the standardization hypothesis through the metric variability presented by series of vessels produced in different economic contexts. By comparing different economic situations belonging to the same culture (Indian), we have been able to isolate the parameter "intensity of production" in order to test the hypothesis according to which rate of production plays on motor habits that, in turn, affect the degree of standardization. Our results show that rate of production does affect the degree of standardization. However, when comparing ceramic assemblages from different cultures (Filipino), it appears that emic conceptions of standardization also play on metric variability. Only in a high-rate production situation do we have motor habits that transcend emic conceptions of standardization. It enables us to quantify, even if hypothetically, the relative range of variability expected on vessels made within different contexts of production. When applied to archaeological data, these results show that some ceramic production considered up to now as highly standardized may correspond, in fact, to relatively small-scale production.

By way of conclusion, let us emphasize that archaeological data need to be interpreted by reference to quantified ethnographic data. Quantification has to be cross-cultural so that it can be applied in any cultural context. In order to elaborate cross-cultural referents or regularities, technical facts have to be studied in terms of resources and constraints (Roux 1999). The constraints considered here are the motor habits underlying the production of standardized series of vessels. The cultural aspect is taken into account through the emic conceptions of standardization. One of the aims of ethnoarchaeological study is also to assess the context into which constraints transcend emic conceptions. Ultimately, such an approach enables us to test our interpretations against empirical data.
Acknowledgments. This research was supported by a grant from the French Institute of Pondicherry (Ministry of Foreign Affairs). A first version of the paper was presented at the 1994 World Archaeological Congress in New Delhi, India. I thank J. Pouchepadass for support of the project and M.L.K. Murty for his precious collaboration in the field. Comments on earlier drafts of this paper by Patricia L. Crown and anonymous reviewers are especially acknowledged. I also kindly thank Tim Kohler for critique, suggestions, and editorial comments. I am grateful to Jehanne Féblot-Augustins and Carol Kramer for their help in improving my English. Figures were drafted by Gérard Monthel (CNRS, UMR7055). The Spanish abstract was kindly translated by Jean-François Bouchard.

\section{References Cited}

Arcelin-Pradelle, C., and F. Laubenheimer

1982 Une Mission d'Archéo-Ethnologie: les Ateliers de Potiers Traditionnels dans les Provinces de Valencia et de Castellén (Espagne). Techniques et Technologies. Sources Documentaires 5:27-52. Institut de Recherches Méditerranéennes, Université de Provence.

1985 La Notion de Série de Production en Céramique Tournée. Techniques et Technologies. Sources Documentaires 7:129-139. Institut de Recherches Méditerranéennes, Université de Provence.

Arnold, D., and A. L. Nieves

1992 Factors Affecting Ceramic Standardization. In Ceramic Production and Distribution: an Integrated Approach, edited by G.J. Bey III and C.A. Pool, pp. 113-214. Westview Press, Boulder, Colorado.

Benco, N.

1988 Morphological Standardization: An Approach to the Study of Craft Specialization. In A Pot for All Reasons: Ceramic Ecology Revisited, edited by C. Kolb and L. Lackey, pp. 57-72. Temple University, Philadelphia.

Blackman, M. J., G. J. Stein, and P. B. Vandiver

1993 The Standardization Hypothesis and Ceramic Mass Production: Technological, Compositional and Metric Indexes of Craft Specialization at Tell Leilan, Syria. American Antiquity 58:60-8.

Bril, B., V. Roux, and G. Dietrich

2000 Skills Involved in the Knapping of Chalcedony Beads: Motor and Cognitive Characteristics of a Complex Situated Action. In Cornaline de l'Inde: Des pratiques techniques de Cambay aux techno-systèmes de l'Indus, edited by V. Roux, pp. 207-332. Editions de la MSH, Paris (English CD-Rom enclosed).

Coren, S., L. M. Ward, and J. T. Enns

1994 Sensation and Perception. 4th ed. Harcourt Brace, Fort Worth, Texas.

Costin, C. L.

1991 Craft Specialization: Issues in Defining, Documenting and Explaining the Organization of Production. In Advances in Archaeological Method and Theory, Vol. 3, edited by M. B. Schiffer, pp. 1-56. University of Arizona Press, Tucson.

2000 The Use of Ethnoarchaeology for the Archaeological Study of Ceramic Production. Journal of Archaeological Method and Theory 7:377-403.

Costin, C. L., and M. B. Hagstrum

1995 Standardization, Labor Investment, Skill, and the Organization of Ceramic Production in Late Prehispanic Highland Peru. American Antiquity 60:619-639. 
Eerkens, J. W., and R. L. Bettinger

2001 Techniques for Assessing Standardization in Artifact Assemblages: Can We Scale Material Variability? American Antiquity 66:493-504.

Feinman, G. M., S. Upham, and K. G. Lightfoot 1981 The Production Step Measure: An Ordinal Index of Labor Input in Ceramic Manufacture. American Antiquity $46: 871-884$

Gallay, A.

1986 L'archéologie Demain. Belfond, Paris.

Kvamme, K. L., M. T. Stark, and W. A. Longacre

1996 Alternative Procedures for Assessing Standardization in Ceramic Assemblages. American Antiquity 61:116-126.

London, G. A.

1991 Standardization and Variation in the Work of Craft Specialists. In Ceramic Ethnoarchaeology, edited by W.A. Longacre, pp. 182-204. University of Arizona Press, Tucson.

Longacre, W. A.

1991 Sources of Ceramic Variability among the Kalinga of Northern Luzon. In Ceramic Ethnoarchaeology, edited by W.A. Longacre, pp. 95-11. University of Arizona Press, Tucson.

1999 Standardization and Specialization: What's the Link? In Pottery and People, edited by J. Skibo and G. Feinman, pp. 231-267. University of Utah Press, Salt Lake City.

Longacre, W. A., K. L. Kvamme, and M. Kobayashi

1988 Southwestern Pottery Standardization: An Ethnoarchaeological View from the Philippines. Kiva 53:101-112.

Rice, $\mathrm{P}$.

1989 Ceramic Diversity, Production and Use. In Quantifying Diversity in Archaeology, edited by R. D. Leonard and G. T. Jones, pp. 109-117. Cambridge University Press, Cambridge.

1991 Specialization, Standardization and Diversity: a Retrospective. In The Ceramic Legacy of Anna O. Shepard, edited by R. L. Bishop and F. W. Lange, pp. 257-279. University Press of Colorado, Boulder, Colorado.

Roux, V., and D. Corbetta

1989 The Potter's Wheel: Craft Specialization and Technical competence. Oxford and IBH Publishing, New Delhi.

Roux, V.

1999 Ethnoarcheology and the Generation of Referential Models: The Case of Harappan Carnelian Beads. In EthnoAnalogy and the Reconstruction of Prehistoric Artefact Use and Production, edited by L. Owen and M. Porr, pp. 153-17. MoVince Verlag, Tübingen.

Saraswati, B., and N. K. Behura

1964 Pottery Techniques in Peasant India. Anthropological Survey of India, Vol. 13, Calcutta.

Sinopoli, C

1988 The Organization of Craft Production at Vijayanagara, South India. American Anthropologist 90:580-597.

Stark, B. L.

1995 Problems in the Analysis of Standardization and Spe- cialization in Pottery. In Ceramic Production in the American Southwest, edited by B. Mills and P. Crown, pp. 231-267. University of Arizona Press, Tucson.

\section{Notes}

1. The ethnoarchaeological survey was carried out in Andhra Pradesh, in February 1991, in collaboration with Prof. M.L.K. Murty (University of Hyderabad).

2. Index of regularity of walls $=($ Thick1/L-Thick1/R $) 2+$ (Thick2/L-Thick2/R)2 + (Thick3/L-Thick3/R)2. $(\mathrm{L}=$ left, $\mathrm{R}$ $=$ right). Likewise for thickness and width of the lip.

3. The Least Significant Difference (LSD) is the minimum difference between the two groups that can be considered statistically significant.

4. For kura catti (Figure 3), height differentiates between potter $A$ and potters $C, D, E, G$, potter $F$ and potter C, D, E, G, and potter B and potters C, D, G. Maximum diameter differentiates between potter $A$ and potters $C, D, E, F, G$, and potters $\mathrm{D}$ and $\mathrm{E}$. Aperture differentiates between potter $\mathrm{A}$ and potters C, D, E, F, G, potters B and C, E, F, G, and potters D and E, F, G (Games-Howell test). For ralla catti (Figure 4), height differentiates potter A and potters B, D, E, G, potter B and potters $\mathrm{D}, \mathrm{E}, \mathrm{G}$, and potter $\mathrm{F}$ and potters $\mathrm{D}$ and $\mathrm{G}$. Maximum diameter differentiates between potter $B$ and potters $D, E, F, G$, potter $A$ and potters D, E, F, G, and potters $G$ and $\mathrm{E}$. Aperture differentiates between potter $\mathrm{B}$ and potters $\mathrm{A}$, D, E, F, G, and potter D and potters A, E, F, G (GamesHowell test). For pedda bana (Figure 5), height differentiates between potter $F$ and potters $B, E$, potter $G$ and potters B, E, and potter $\mathrm{E}$ and potters $\mathrm{A}, \mathrm{B}, \mathrm{D}$. Maximum diameter differentiates between potter $\mathrm{E}$ and potter $\mathrm{A}, \mathrm{B}, \mathrm{D}, \mathrm{F}, \mathrm{G}$, and potters $G$ and $B$. Aperture differentiates between potter $F$ and potters A, B, D, E, potter $G$ and potters A, D, E, potter B and potters $\mathrm{D}, \mathrm{E}$, potter $\mathrm{A}$ and potters $\mathrm{D}, \mathrm{E}$, and potters $\mathrm{D}$ and $\mathrm{E}$ (Games-Howell test).

5. Height differentiates between potters 5 and 1, 2, 4, 6, potters 3 and $1,2,4,6$, potters 1 and 2, 4, 6, potters 6 and 4 , and potters 2 and 4 . Aperture differentiates each potter from each other. Maximum diameter differentiates between two groups of potters: potters 3, 5, 6 and potters 1, 2, 4 (GamesHowell test).

6. "Unlike mechanical scales that determine weight within an invariant unit of error, human appreciation of heaviness is scaled relative to object weight. This value ( 2 percent) has come to be called the Weber's fraction for heaviness" (Eerkens and Bettinger 2001:495).

Received March 25, 2002; Revised October 31, 2002;

Accepted April 17, 2003. 